\title{
MARGIN OF APPRECIATION - A NOTE TOWARDS A SOLUTION FOR THE PACIFIC?
}

\author{
Petra Butler*
}

This "think piece," which is aimed at contributing to the debate over a Pacific human rights mechanism, firstly identifies and exemplifies some of the challenges between tradition and culture and human rights embodied in the main human rights conventions. Part III gives a brief overview of the doctrine of margin of appreciation as used by the European Court of Human Rights. The last Part analyses whether the doctrine of margin of appreciation will be able to withstand and adequately balance any "challenges" from the unique traditions and culture of the Pacific. This essay is intended as the beginning of a dialogue over the value of a margin of appreciation approach in the Pacific, as opposed to a contribution as such to the enormous literature on the margin of appreciation approach in Europe. It argues that there is much use in framing some of the Pacific debates over the application of human rights through the European approach.

\section{INTRODUCTION}

I met Professor Tony Angelo 17 years ago when I came to Victoria University to do my LLM. He has been a great mentor ever since. When the idea was mooted to honour Tony with a Festschrift, in the form of a special issue of this journal, to which he has made an enormous contribution over the years, I, of course, wanted to be involved. One of Tony's major research areas is the Pacific. One of my main research areas is human rights so I thought it was appropriate to combine our two areas of interest and suggest how the European doctrine of margin of appreciation could be a model for the Pacific in a combination of the New Zealand and European inheritance of both Tony and myself

Recently, debate over whether the Pacific region ${ }^{1}$ should have its own regional human rights charter and mechanisms has, after a long hiatus, gained considerable momentum. ${ }^{2}$ One of the main

* Senior Lecturer, Victoria University of Wellington, Associate Director New Zealand Centre for Public Law. I wish to thank my colleague, Geoff McLay, and my husband, Andrew Butler, for all their valuable comments on earlier drafts of this paper. 
concerns expressed during the recent debate (as was indeed the case on the previous occasions) is that the adoption of a Pacific region human rights instrument will result in Pacific Islands' unique culture and traditions ${ }^{3}$ having to succumb to a "Western" human rights culture. ${ }^{4}$

In many Pacific Island countries, local disputes are determined with the help of local customs and traditions permeate daily life. Human rights law, on the other hand, holds sway mainly in the courts. It is an issue about which international NGOs especially talk, and is a topic raised by foreign dignitaries visiting the Islands. The separation between customary methods and daily life and court methods of dispute settlement and official speak can foster distorted views, with the result that the courts rely on foreign values or that custom is irrelevant. ${ }^{5}$ Those views and fears can be used to

1 A map of the Pacific can be found under: http:www.mapsouthpacific.com (last accessed 23 Jan 2009). For the purpose of this paper the Pacific region embraces three distinct cultural and linguistic groups of islands: Polynesia which stretches across the Pacific from New Zealand to the Easter Islands and north to Hawaii (Polynesia includes: French Polynesia, Pitcairn, Easter Island, the Cook Islands, Niue, Tonga, American Samoa, Samoa, Tokelau, Tuvalu, and Wallis and Futuna); Melanesia which curves down from New Guinea to the Solomon Islands, Vanuatu, New Caledonia, and Fiji; and Micronesia which lies between Hawaii and the Philippines consisting of thousands of small islands which make up the Marshall, Caroline, Mariana, and Gilbert groups (these geographical island groups are divided into the following states: Republic of the Marshall Islands, the Federated States of Micronesia, the Territory of Guam, the Commonwealth of the Northern Mariana Islands, the Republic of Palau, the Republic of Kiribati, and Nauru. It needs to be noted that this is a geographic description of the South Pacific. This paper does not give a definite answer to the question of which states should be members to a Pacific Human Rights Charter since some of the Island States are politically "associated" with France, the United States or New Zealand). The region's states are far apart from each other and often only accessible by long boat trips. A multitude of cultures, traditions, and languages exists within the Pacific region. Only 0.1 per cent of the world's population lives in the Pacific region, but the region contains one-third of the world's languages (Jennifer Corrin Care "Cultures in Conflict: The Role of the Common Law in the South Pacific" (2002) 6 Journal of South Pacific Law, footnote 2 http://law.vanuatu.usp.ac.fj (last accessed 23 Jan 2009)).

2 See, for example, Australia: the Parliamentary Human Right Sub-Committee in October 2008 called for submissions in regard to its inquiry into international and regional human rights mechanisms and models for the Asia-Pacific; Strategies for the Future (conference Samoa, April 2008): papers to be published in (2009) 40 VUWLR (forthcoming); Petra Butler "Human Rights in the Pacific" PIPSA conference, November 2005 in Suva/Fiji.

3 As far as this paper uses "custom" or culture and traditions it has to be pointed out that those concepts are difficult to define. The New Zealand Law Commission stated in its study paper that there was no settled definition of custom law. It warned against one and went on to adopt the term "custom law" to encompass references to "custom" and "customary law" and to describe the "values, principles and norms that members of a cultural community accept as establishing standards for appropriate conduct", New Zealand Law Commission Converging Currents: Customs and Human Rights in the Pacific (Wellington, 2006) study paper 17, para 4.23 .

4 Compare, for example, Unasa Vaá "Samoan Custom and Human Rights: An Indigenous View" (2009) 40 VUWLR (forthcoming).

5 See New Zealand Law Commission Converging Currents: Custom and Human Rights in the Pacific, above n 3, Foreword. 
further a specific political aim and by certain groups to advocate for a continuation of the status quo. However, as Jalal has pointed out: "We [the Pacific Island peoples] are not lesser people entitled to lesser rights." 6

Starting with the premise that human rights are governed by a universal value system, and not just Western values, ${ }^{7}$ this essay argues that the concern that a human rights protection mechanism necessarily will not have room for traditions and customs can be overcome. In particular, the experience of the European Convention on Human Rights shows, this paper argues, that the demands of human rights compliance and the different cultural, social, and historical identities of nation states can be balanced. I argue that the European doctrine of margin of appreciation used by the European Court of Human Rights would be a useful starting point to employ in a Pacific regional human rights instrument to find the appropriate balance between human rights protection of the individual or group as enunciated in international human rights instruments, like the ICCPR ${ }^{8}$ or the ICESCR, ${ }^{9}$ and the treasuring of the traditions and customs of each individual Pacific Island society.

\section{HUMAN RIGHTS IN THE PACIFIC}

Before it can be examined whether the doctrine of margin of appreciation could be a useful tool to employ in the Pacific context this paper will give a brief background on the status of a regional human rights mechanism and the use to date of human rights norms in decisions of the Island courts.

\section{A General}

In 1985, LAWASIA ${ }^{10}$ started examining the possibility of a regional human rights Charter for the Pacific. The meeting was attended by 63 government and NGO delegates. However, the

6 Imrana Jalal "Why do we need a Pacific Regional Human Rights Commission?" (2009) 40 VUWLR (forthcoming).

7 See in regard to that debate specifically tailored to the Pacific: Sue Farran Human Rights in the South Pacific (Routledge/Cavendish, London, 2009) chapter 3. See also H Amankwah "Fundamental human rights: roots, fruits, myths and realities" 17 (1989) Melanesian Law Review 43, 44-45. See in regard to universalism versus cultural relativism especially in regard to indigenous women's rights: Claire Charters "Universalism and Cultural Relativism in the Context of Indigenous Women's Rights" Human Rights Research (www.victoria.ac.nz/nzcpl/HRRJ/vol1/Charters.pdf) (last accessed 3 March 2009).

8 International Covenant on Civil and Political Rights, GA res 2200A (XXI) 21 UN GAOR Supp (No 16) at 52, UN Doc A/6316 (1966), 999 UNTS 171, entered into force 23 March 1976.

9 International Covenant on Economic, Social and Cultural Rights, GA res 2200A (XXI), 21 UN GAOR Supp (No 16) at 49, UN Doc. A/6316 (1966), 993 UNTS 3, entered into force 3 January 1976.

10 LAWASIA is a non-governmental organisation comprising lawyers in Asia and the Pacific; http://lawasia.asn.au/welcome (last accessed 14 February 2009). 
majority of delegates came from Asia, Australia, and New Zealand. ${ }^{11}$ In 1989 a draft Pacific Charter of Human Rights ${ }^{12}$ was adopted at a meeting held in Samoa. However, the Charter did not mature beyond a draft status since it failed to gain any support from the Pacific Island Governments. ${ }^{13}$ Jalal in her paper lists a number of reasons why the LAWASIA draft charter remained a draft, including, inter alia: ${ }^{14}$

- inadequate space for the participation of stakeholders other than the governments, and lack of local Pacific ownership,

- those participating at the government level were not of high enough rank to have real impact,

or

- it may also have been that the time was not ripe for this development because of a general and widespread lack of human rights awareness in the region. ${ }^{15}$

After over a 15 year lacuna a renewed call for a Pacific Charter in combination with, or as an alternative to, a Pacific mechanism has been made under Strategic Objectives 12.1 and 12.5 of the Pacific Plan, therefore, right out of the heart of the Pacific nations. ${ }^{16}$ Already in 2000 the Biketawa Declaration which was adopted by Pacific Islands Forum Leaders included a statement holding: ${ }^{17}$

Belief in the liberty of the individual under the law, in equal rights for all citizens regardless of gender, race, colour, creed or political belief and in the individual's inalienable right to participate by means of free and democratic political process in framing the society in which he or she lives.

Through this declaration the Leaders have acknowledged that the protection and promotion of human rights is clearly critical to successful societies. In 2004 a Pacific Islands Human Rights Consultation was held in Fiji with over 80 participants from non-governmental organisations, government observers, national institutions, and international and regional organisations attending.

11 Jalal, above n 6. See also for another detailed account Sue Farran Human Rights in the Pacific (RoutledgeCavendish, London, 2009) 283.

12 LAWASIA Human Rights Committee, Draft Pacific Charter of Human Rights and Explanatory Memoranda (Kensington, NSW, 1989).

13 Jalal, above n 6. and Petra Butler "A Human Rights Charter for the Pacific" [2005] HRRJ http://www.victoria.ac.nz/nzcpl/HRRJ/vol3/Butler.pdf

14 Jalal, above $n 6$.

15 Farran, above n 7, 285.

16 Pacific Islands Forum Secretariat, The Pacific Plan (Suva, revised version 2007) 17, 18 (available through the Pacific Forum Secretariat website www.forumsec.org.fj/pages.cfm/about-us/the-pacific-plan/ (last accessed 12 February 2009)).

17 www.forumsec.org.fj/news/2000/Oct06.htm (last accessed 22 October 2005). 
In that consultation it was recommended (interestingly) that discussions about traditional and customary rights in relation to human rights be narrowed as far as possible to specific issues and be determined on their merits. ${ }^{18}$

\section{B Human Rights in Practice}

On a practical level it has to be noted that most of the Pacific Island states have a Constitution which includes a catalogue of rights for which the ECHR has often been a model. Some of the Constitutions also reflect modern concepts, like protection of the environment ${ }^{19}$ or group rights. $^{20}$ In the last 10 years the Pacific Island courts have started to use their constitutional human rights framework when considering domestic issues often in situations where a custom or tradition dictated an outcome prima facie infringing human rights. Furthermore, in many the Pacific Island states fundamental principles of common law and equity have also formed part of their legal system and afford human rights protection. ${ }^{21}$ In addition, the Constitutions of the Federated States of Micronesia and Palau specifically refer to "traditional rights." 22 The New Zealand Law

18 Pacific Islands Human Rights Consultation Concluding Statement and Recommendations (Suva, 3 June 2004) para 29.

19 Constitution of the Republic of Palau 1979, Art VI. Further, the Constitution states that "[h]armful substances such as nuclear, chemical, gas or biological weapons intended for use in warfare, nuclear power plants, and waste materials therefrom, shall not be used, tested, stored, or disposed of within the territorial jurisdiction of Palau without the express approval of not less than three-fourths (3/4) of the votes cast in a referendum submitted on this specific question" - see art XIII s 6; Constitution of the Republic of Vanuatu art 7(d): every person has the fundamental duty to themselves, their descendants and others to safeguard the national wealth, resources and environment.

20 For example, Constitution of Tuvalu, art 29(3): "Within Tuvalu, the freedoms of the individual can only be exercised having regard to the rights or feelings of other people, and to the effect on society."

21 For example, in Police $v$ Ngau [1992] CKHC 3 Dillon J held that it was a "fundamental principle of interpretation that no statute should be so construed as to abrogate a fundamental principle of the common law. For that to happen there must be a clear and unequivocal expression of intention in any statutory provision that that should be so construed." However, see In re the Constitution, Jeremiah v Nauru Local Government Council [1971] NRSC 5 where the Court basically found that no rights existed outside the ones stipulated in the Nauru Constitution.

22 Palau Constitution, Art 5, s 2 states:

"Statutes and traditional law shall be equally authoritative. In case of conflict between a statute and a traditional law, the statute shall prevail only to the extent it is not in conflict with the underlying principles of the traditional law."

Federated States of Micronesia, Art 5 para 2 states similarly:

"The traditions of the people of the Federated States of Micronesia may be protected by statute. If challenged as violative of Article IV [Article IV sets out the human rights catalogue], protection of Micronesian tradition shall be considered a compelling social purpose warranting such governmental action." 
Commission in its comprehensive study on customary rights suggest that most fundamental rights are observed in custom and customary law in the Pacific region. Examples, the Law Commission lists, are, amongst others, the Pacific endorsement of distributive equality and egalitarianism and the international declarations on equal rights. Both suggest the importance of the caring for and, the sharing of, resources; ${ }^{23}$ while respect for the spiritual beliefs of others and the acceptance of missionary teaching demonstrates religious tolerance. ${ }^{24}$ Farran points out that what is evident about customary values is that any exercise of individual rights tends to be subject to those of the group. ${ }^{25}$ International human rights instruments, however, are not unfamiliar with the idea of the group rights. ${ }^{26}$

The wider human rights framework suggests that the incorporation of human rights in the life of the Pacific Islanders will not result in a fundamental change in the life of the Islands or their legal framework. Pacific Island courts have also already measured traditions and customs against human rights as incorporated in their constitutions.

In 2004 the Samoan Supreme Court had to consider the constitutionality of banishment. ${ }^{27}$ Banishment is a customary procedure which allows the village council to banish people from the village. In the particular case the family had to leave the village within a couple of hours trying to take as much of their possessions with them as possible (the rest had to be left behind). The grounds for banishment were unsubstantiated. The decision by the village council was made without, what a Westerner would consider, a "fair trial." The plaintiff claimed an infringement of his right to a fair trial and his right to freedom of movement both guaranteed by the Samoan Constitution. ${ }^{28}$ The Supreme Court held that the Village Fono Act 1990 (which authorises punishment for village misconduct in accordance with the custom and usage of the village) did not confer on the village council legal authority to order banishment from the village since to do so would be tantamount to winding back the clock of progress. With evolution of time the accompanying developments brought about amongst other things changes in lifestyle, perception and attitudes. Banishment from the village may now be viewed as not only preventive but also punitive. And furthermore the Court held citing Marsack CJ in Mose v Masame: ${ }^{29}$

23 New Zealand Law Commission Converging Currents: Custom and Human Rights in the Pacific, above $\mathrm{n} 3$, paras 6.5 and 6.6 .

24 Ibid, para 6.8.

25 Farran, above n 7, 86.

26 See, for example, ICCPR, Art 27 and also on a Pacific level Fiji Constitution 2000, s 6.

27 Leituala v Mauga [2004] WSSC 9.

28 Independent State of Western Samoa 1960, s 9 (Fair Trial) and s 12 (Rights regarding freedom of speech, assembly, association, movement and residence).

29 Mose v Masame (1930-1939) WSLR 140, 142. 
... the courts cannot lend their approval to any custom, however ancient, which denies to an accused person a right freely available to the lowliest member of a civilised Christian community. It must not be understood as saying that Samoan Custom will not be recognised. The court realises that custom and law can exist side by side and the court will not interfere with any custom which is just and in the best interests of the community.

The Court also had regard to the Convention on the Rights of the Child (UNCROC) since young children were affected by the banishment. ${ }^{30}$

The courts have been especially asked to balance customs and traditions with human rights in the area of family disputes. In Melanesia the payment of a price for the bride customarily ensures custody of children to the father. This custom has been overruled through the innovative use of UNCROC to secure the protection of children in family law. ${ }^{31}$ On the other hand, the High Court of Tuvalu in a child custody judgment at the beginning of 2005 refused to engage in a discussion of the application of CEDAW ${ }^{32}$ or UNCROC (both of which Tuvalu has ratified). Firstly, discrimination on the grounds of sex was permitted especially with reference to land. Secondly, no laws had been passed to implement their provisions although, prior to that, the court may take cognisance of their terms as an aid to the determination of the true construction of a provision of the law where there is any difficulty in its interpretation. ${ }^{33}$ In this particular case the domestic legislation endorsed the Tuvaluan custom and usage which was itself supported in a number of places in the Constitution.

The Supreme Court of Vanuatu in Public Prosecutor v Kota held that the Chiefs could not force a woman to return to her husband (she had claimed freedom of movement). The Court held that the Chiefs must realise that any laws they wished to exercise under custom were subject to the individual's fundamental rights and their freedom of movement as guaranteed by the Constitution. ${ }^{34}$

A village court in Papua New Guinea, applying customary law, ordered a woman to pay compensation for adultery in accordance with custom. As women have no independent means of income in Papua New Guinea, she was unable to pay and, as a result, was imprisoned for 32 weeks.

30 Convention on the Rights of the Child, GA res.44/25, annex, 44 UN GAOR Supp (No 49) 167, UN Doc A/44/49 (1989), entered into force 2 September 1990.

31 L Tamata "Application of Human Rights Conventions in the Pacific Island Courts" [2000] JSPL 5, 7 (working paper). The Solomon Islands High Court also put the interest of the children before customs in a custody case Sukutanona v Houanihou Civil Appeal Case No 7 (9 Dec 1981) (HC).

32 Convention on the Elimination of All Forms of Discrimination against Women, GA res.34/180, 34 U.N GAOR Supp (No. 46) at 193, UN Doc A/34/46, entered into force 3 September 1981.

33 Tepulolo v Pou [2005] TVHC 1.

34 [1993] VUSC 8. 
On appeal, however, the National Court of Justice read the customary laws subject to equality provisions of the Papua New Guinean Constitution and overturned the Village Court's order. ${ }^{35}$

These examples of case law from around the Pacific show that human rights have not been ignored but, on the contrary, have been an important consideration in the decision-making process. Sometimes the decisions have been against customs and traditions. For example, in a region where male dominance has prevailed and is jealously guarded, CEDAW was nonetheless ratified by most states. Courts, at least in the cases that I have considered, have tried to rule against discrimination against women. However, the decisions also display an awareness of the importance of customary rights and procedures. Nevertheless in discussions, like those during the Strategies for the Future Human Rights in the Pacific conference which was held in Apia, Samoa in April 2008, ${ }^{36}$ strong concern was still voiced, especially by young people, that any human rights instruments could be used to eradicate customs and traditions in the Pacific.

It is the author's argument that the doctrine of margin of appreciation would be a good basis to put all doubts about an impossibility of balancing customs and "Western style" human rights to rest. The doctrine will provide a good foundation for a balance between to two perceived diametrically opposed concepts.

\section{MARGIN OF APPRECIATION}

\section{A General Introduction}

The European Court of Human Rights (ECtHR) is established under the European Convention for the Protection of Human Rights and Fundamental Freedoms (ECHR) which was adopted in $1950^{37}$ and to which 47 countries are parties. ${ }^{38}$ The ECHR is an international treaty under which the member States of the Council of Europe promise to secure fundamental civil and political rights, not only to their own citizens (currently numbering 800 million people) but also to everyone within their jurisdiction. The Convention's importance lies not only in the scope of the rights which it protects, but also in the protection system set up in Strasbourg to examine alleged violations and to ensure that the States comply with their obligations under the Convention. The ECtHR, set up in 1959, is an international court with jurisdiction to rule, through binding judgments, on individual

35 Application of Wagi Non [1991] PGNC 2; $\begin{array}{lllll}\text { Mt } & \text { Hagen } & \text { N949 } & 199\end{array}$ www.paclii.org/pg/cases/PGNC/1991/2.html (last accessed 2 March 2009).

36 See the conference papers and proceedings in a forthcoming special issue of the VUWLR.

37 European Convention on Human Rights, Preamble.

38 www.coe.int (last accessed 10 March 2009). Mexico, the Holy Sea, the United States of America, Canada, and Japan have observer status. 
and inter-State applications alleging violations of the ECHR. ${ }^{39}$ Since 1998 the Court has operated on a full-time basis. It is made up of 47 judges, one appointed by each party to the ECHR. It handles several thousand cases a year. 40

Margin of appreciation is the doctrine the ECtHR developed to apply to certain provisions of the ECHR. It generally refers to the amount of discretion the ECtHR gives national authorities in fulfilling their obligations under the ECtHR. Yourow in his influential text on the margin of appreciation defines it as: 41

[T] he latitude of deference or error which the Strasbourg organs will allow to national legislative, executive, administrative and judicial bodies before it is prepared to declare a national derogation from the Convention, or restriction or limitation upon a right guaranteed by the Convention, to constitute a violation of one of the Convention's substantive guarantees. It has been defined as the line at which international supervision should give way to a State Party's discretion in enacting or enforcing its laws.

The term "margin of appreciation" itself does not appear in the Convention text. The ECtHR developed the doctrine as arising from of many ECHR provisions. ${ }^{42}$ Articles often first assert a particular fundamental right which is then followed by a paragraph that is the subject of a limitation. ${ }^{43}$ Especially in regard to Articles 8 to 11 ECHR the Court had to decide how much

39 The European Court of Human Rights The European Court of Human Rights - Some Facts and Figures 1998- 2008 (Strasbourg 2008) 1; Burleigh Wilkins "International Human Rights and National Discretion" (2002) 6 The Journal of Ethics 373, 374.

40 The Court delivered 1560 judgments in 2006; 1503 in 2007; and 1205 in 2008. More than half the judgments delivered by the Court between 1998 and 2008 concerned four of the Council of Europe's 47 member States: Turkey (1,857 judgments), Italy (1,789 judgments), France (613 judgments) and Poland (601 judgments). Of the total number of judgments it has delivered since the 1998 reform, in over $83 \%$ of cases the Court has found at least one violation of the Convention by the respondent State (The European Court of Human Rights The European Court of Human Rights - Some Facts and Figures 1998-2008 (Strasbourg 2008) 5.

41 Howard Charles Yourow Margin of Appreciation Doctrine in the Dynamics of European Human Rights Jurisprudence (Brill, Netherlands, 1996) 13. Less formally the doctrine has been described as: "room for manoeuvre", Steven Greer The Margin of Appreciation: Interpretation and Discretion Under the European Convention on Human Rights (Council of Europe, Human Rights Files No 17, Strasbourg 2000) 5; "breathing space", Howard Charles Yourow "Margin of Appreciation Doctrine in the Dynamics of European Human Rights Jurisprudence" (1987) 3 Conn J Int'l L 111, 118; and "a doctrine of self-restraint", Thomas O'Donnell "The Margin of Appreciation Doctrine: Standards in the Jurisprudence of the European Court of Human Rights" (1982) 4 Hum Rts Q 474, 478.

42 Jeffrey Brauch "The Margin of Appreciation and the Jurisprudence of the European Court of Human Rights: Threat to the Rule of Law" (2005) 11 Columbia Journal of European Law 113, 116.

43 A practice which is found in many modern constitution, for example, the German Basic Law, and the South African Constitution. The Canadian Constitution Act 1982, s 1 has a general limitation clause applicable to all rights states which is also based on the limitation being "demonstrably justified in a free and democratic society"; compare also NZ Bill of Rights Act 1990, s 5. 
deference the Court was prepared to give to its member states in regard to the limitations which state that an interference with a right is justified if it is: ${ }^{44}$

necessary in a democratic society in the interests of [for example] public safety or the economic well-

being of the country, for the prevention of disorder or crime, for the protection of health or morals, or for the protection of the rights and freedoms of others.

The margin of appreciation doctrine, for the purposes of this paper, addresses the limits or intensity of the review of the ECtHR in view of its status as an international tribunal. It amounts to the claim that the ECtHR should often defer to the judgment of national authorities on the basis that the ECHR is an international convention, not a national bill of rights and that national authorities are better placed to respond to historic, cultural or societal needs. ${ }^{45}$

\section{B Margin of Appreciation in Practice}

The question arises as to the circumstances in which and how the Court has used margin of apprectiation. It is not the object of this article to comprehensively review the operation of the doctrine. Rather what I attempt is to suggest how the doctrine might apply in the Pacific. I have therefore illustrated the doctrine through two cases. These two cases, among many, were chosen to illustrate the use of the margin of appreciation doctrine because one is the landmark case on the doctrine (Handyside ${ }^{46}$ ) and the second (Sahin ${ }^{47}$ ) is a relatively recent example of the doctrine's use in regard to an issue which was and still is a highly controversial issue within European society. ${ }^{48}$ Initially, the doctrine was developed to respond to member states' concerns that the Convention rights would unreasonably prohibit them from implementing national security measures. ${ }^{49}$

44 The wording of the limitations in Arts 8 to 11 differs slightly, for example, including national security as a reason to limit Art 8 . It has to be noted that the first in depth discussion of the doctrine in Lawless $v$ Ireland (No 3) (1961) 1 EHRR 15 involved ECHR, Arts 5 and 6.

45 See also Laurence R Helfer \& Anne-Marie Slaughter "Toward a Theory of Effective Supranational Adjudication" (1997) 107 Yale Law Journal 273, 316-317.

46 (1976) 1 EHRR 737.

47 (10 Nov 2005) Application no 44774/98.

48 For example, the German Constitutional Court (BVerfG) had to decide about whether a teacher was allowed to wear a headscarf: BVerfG (24. September 2003) BvR 1436/02 available under http://www.bundesverfassungsgericht.de (last accessed 3 Apr 2009) which held that there need to be at least a legal basis for denying the wearing of a headscarf; in France the National Assembly banned the headscarf in school by law in September 2004 (see http://edition.cnn.com/2004/WORLD/europe/02/10/ france.headscarves/index.html) (last accessed 3 April 2009); for the UK see $R$ (on the application of Begum) $v$ Denbigh High School Governors [2007] 1 AC 100; which suggests some room of allowing the wearing of headscarf/or the right to choose to wear a headscarf .

49 See Sir Humphrey Waldock (President of the Commission) in Lawless v Ireland 1 (1960-1961) ECtHR (ser B) 408 concerning national security measures under conditions of proclaimed national emergency. 
However, the landmark case in regard to the development of the doctrine was Handyside $v$ United Kingdom. The case involved the publication of "The Little Red Schoolbook". The book targeted young readers and included among general life advice controversial encouragements to smoke marijuana and experiment sexually. After receiving complaints about the book, the police searched the publisher's, Richard Handyside's, premises and his books were seized and destroyed. The local Magistrate's Court convicted him of possessing obscene books for gain. Handyside filed a complaint with the ECtHR alleging, amongst other things, that his conviction violated his right to freedom of expression under Article 10 of the ECHR. ${ }^{50}$ In issue was whether the prohibition and seizure by the British authorities of the contentious book and the conviction of its publisher for possessing obscene books was in accordance with the limitation of freedom of expression. ${ }^{51}$ In upholding the ban and conviction, the ECtHR applied an analysis that has become standard in cases involving the margin of appreciation. ${ }^{52}$ The ECtHR first determined whether the publisher's conviction was a breach of his right of freedom of expression which it answered in the affirmative. Next the Court went on to determine whether the prohibition of the book (that means, the determination of the book as obscene) was "necessary" in a "democratic society" for the "protection of morals". ${ }^{5}$ The ECtHR, by examining the language of Article 10(2), found first that the United Kingdom's obscenity laws met the requirement of "prescribed by law." The Court also found that the United Kingdom acted to protect a legitimate aim - morals - one of the aims specifically mentioned in Article 10(2). ${ }^{54}$ The key question for the ECtHR, however, was whether the United Kingdom's actions were "necessary" to further that aim. ${ }^{55}$ For the purpose of this paper, the following statements of the Court are of importance: First, the ECtHR noted that "[t]he Convention leaves to each Contracting State, in the

50 Other cases, involving ECHR, Arts 8-11 and which further cemented the doctrine are: Dudgeon v United Kingdom (30 January 1981) ser A no 45; Müller v Switzerland (24 May 1988) ser A no 133; Ahmed v United Kingdom (2 September 1998) 1998-VI ECtHR 2356;.

51 ECHR, Art 10(2) provides:

The exercise of these freedoms, since it carries with it duties and responsibilities, may be subject to such formalities, conditions, restrictions or penalties as are prescribed by law and are necessary in a democratic society, in the interests of national security, territorial integrity or public safety, for the prevention of disorder or crime, for the protection of health or morals, for the protection of the reputation or rights of others, for preventing the disclosure of information received in confidence, or for maintaining the authority and impartiality of the judiciary.

52 Brauch, above n 42, 118.

53 Handyside $v$ United Kingdom, above n 46, para 48.

54 Idem.

55 Idem. 
first place, the task of securing the rights and freedoms it enshrines". ${ }^{56}$ Furthermore, the Court added that in particular in the area of morals ${ }^{57}$

State authorities are in principle in a better position than the international judge to give an opinion on the exact content of these requirements as well as on the 'necessity' of a 'restriction' or 'penalty' intended to meet them.

And the Court went on to point out: ${ }^{58}$

The requirements of morals varies from time to time and from place to place, especially in our era which is characterised by a rapid and far-reaching evolution of opinions on the subject.

The Court then determined what "necessary" meant and concluded that it meant a "pressing social need". ${ }^{59}$ While the Court recognised a broad margin of appreciation, it emphasised that the margin was not "unlimited", and that "[t]he domestic margin of appreciation thus goes hand in hand with a European supervision. Such supervision concerns both the aim of the measure challenged and its 'necessity'". ${ }^{60}$ When balancing the publisher's right to freedom of speech with the United Kingdom's need to protect morals, the ECtHR held in favour of the United Kingdom especially due to the young age of the children the book was targeting.

In another interesting example, the margin of appreciation played a significant role in the 2005 case of Leyla Sahin $v$ Turkey. The case involved a university student from a traditional family of practising Muslims, who considered it her religious duty to wear the hijab. Following a ban on beards and headscarves at the university she was on several occasions refused entry to exams and lectures, but was not suspended for wearing the Islamic headscarf. The student alleged that a ban on wearing the Islamic headscarf in higher-education institutions violated her rights and freedoms under Articles 8, 9, 10 and 14 of the ECHR. The ECtHR carefully recounted the relevant modern Turkish history by, amongst other things, referring to the fact that at the time of the Ottoman Empire both the central government and religious groups required people to dress in accordance with their religious affiliations. The reforms introduced by the Republic on the question of dress were inspired by evolution of society in the nineteenth century and sought, first and foremost, to create a religionfree zone in which all citizens were guaranteed equality, without distinction on the grounds of religion or denomination. ${ }^{61}$ The ECtHR gave a detailed account of the laws surrounding religious

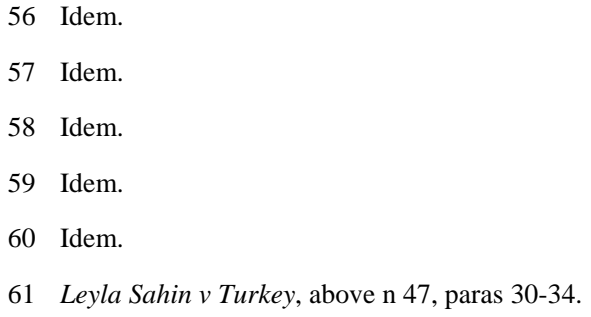


attire in general and at Istanbul University and the decisions of the Turkish Constitutional Court in regard to such laws. The Turkish Constitutional Court in its judgments had placed a considerable amount of weight on Turkey's constitutional commitment to securalism and the need to protect it. ${ }^{62}$ The description of the law in Turkey was followed by a detailed comparative analysis starting by acknowledging that: 63

for more than twenty years the place of the Islamic headscarf in State education has been the subject of debate across Europe. In most European countries, the debate has focused mainly on primary and secondary schools. However, in Turkey, Azerbaijan and Albania it has concerned not just the question of individual liberty, but also the political meaning of the Islamic headscarf. These are the only member States to have introduced regulations on wearing the Islamic headscarf in universities.

The Court acknowledged that it was not possible to discern throughout Europe a uniform conception of the significance of religion in society. Therefore, the meaning or impact of the public expression of a religious belief differed according to time and context. As a result, the regulation of religious expression in public will vary from one country to another according to national traditions and the requirements imposed by the need to protect the rights and freedoms of others and to maintain public order. Consequently, it was the choice ("up to a point") of the member state as to what extent and form such regulations should take as it will depend on the specific domestic context. ${ }^{64}$ The Court continued: ${ }^{65}$

This margin of appreciation goes hand in hand with a European supervision embracing both the law and the decisions applying it. The Court's task is to determine whether the measures taken at national level were justified in principle and proportionate [...]. In delimiting the extent of the margin of appreciation in the present case, the Court must have regard to what is at stake, namely the need to protect the rights and freedoms of others, to preserve public order and to secure civil peace and true religious pluralism, which is vital to the survival of a democratic society.

In both cases the ECtHR carefully did a comparative analysis. In both cases the comparative picture was complex. In both cases the Court ultimately allowed the member state its margin of appreciation. A Pacific human rights court or commission similarly faced with the question of Maori women's speaking rights on the marae might take into the Treaty of Waitangi, New Zealand's history and might conduct a comparative analysis to decide whether that practice is discriminatory compared to the right to equality or freedom from discrimination according to a regional human

62 Ibid, paras 36-54.

63 Ibid, paras 55 and 56-65.

64 Ibid, para 109.

65 Ibid, para 110. 
rights instrument. ${ }^{66}$ Further, a regional human rights court or commission might be asked to decide whether the Samoan custom ${ }^{67}$ that the male heir succeeds to the family's title, gets possession of family lands, and represents the family in the village council or fono is discriminatory. A comparative analysis might reveal that this is a practice widespread in the Pacific (and until not that long ago also in Europe and other parts of the world). ${ }^{68}$

\section{Conclusion}

By 2005 the Court had implemented the margin of appreciation doctrine in over 700 cases, ${ }^{69}$ signalling that the doctrine has become an integral part of the ECtHR's jurisprudence. Two broad categories of cases can be identified in which the ECtHR has taken national authorities to be better placed and has deferred to their judgment. The first category includes cases where, in the view of the Court, there is no consensus among member states on "how much" human rights individuals have. The approach of the ECtHR has been that the less consensus there is among member states on whether something counts as a human rights violation, the better placed national authorities are to decide on the matter and the more deferential the Court has to be in its review. This use of the margin of appreciation has, by and large, been used when interpreting personal sphere rights (Articles 8-11 ECHR), such as in Handyside and Sahin, and in particular restrictions based on public morals. The idea has been that in the absence of a uniform conception of public morals in Europe, member states are "better placed" to assess local values and their application to particular cases. ${ }^{70}$

66 The author does not wish to come to a conclusion on that issue but see Claire Charters "Universalism and Cultural Relativism in the Context of Indigenous Women's Rights" Human Rights Research (www.victoria.ac.nz/nzcpl/HRRJ/vol1/Charters.pdf) (last accessed 3 Mar 2009) 3. It also has to be noted that the author assumes that a regional human rights instrument will contain similar provisions to the ICCPR or ECHR and maybe the ICESCR.

67 See Unasa Vaà, above n 4.

68 It might also take into account the decision of the South African Constitutional Court in Bhe $v$ Khayelitsh Magistrate (CCT 49/03) 15 Oct 2004 where the Court held that an equivalent practice was discriminatory. Langa DCJ further pointed out that "It should however not be inferred ...that customary law can never change and that it cannot be amended or adjusted by legislation," Bhe v Khayelitsh Magistrate (CCT 49/03) 15 Oct 2004 para 44. See also: Submission of the Legal Literacy Project, Tuvalu National Council of Women, Tuvalu Third Session of the Universal Periodic Review Working Group, 1-12 December 2008, NGO Submission to the United Nations Universal Periodic Review (www2.ohchr.org/english/bodies/cedaw/docs/ngos/LLP_Tuvalu_44.pdf (last accessed 11 Mar 2009) where concern is expressed that land scarcity is a pressing problem in Tuvalu and the discriminatory land laws put women in a further disadvantaged position. Section 15 of the Native Lands Act (NLA) 1956 and section 9 of the Tuvalu Lands Code 1962 confer more advantages on the children of first spouses over second spouses, and allow for more lands to be given to the eldest son than the daughters in the distribution of lands.

69 Greer, above n 41, 5.

70 This stance has been criticised as lending weight to the idea of moral relativism and compromising the universality of human rights see Eyal Benvenitsti "Margin of Appreciation, Consensus, and Universal Standards" (1999) 31 International Law and Politics 843. Also Brauch points out that in his view the Court 
The second category comprises cases where the Court defers to the decision of the national authorities because the latter are better placed to decide on politically sensitive issues within a particular member state. This category includes the case law on derogation under Article 15 . The Court has been very reluctant to review whether derogation under Article 15 is justified, on the basis that national authorities are "better placed" to assess the exigencies of the situation. ${ }^{71}$

In regard to Articles 5 and 6 (which protect liberty, security, and the right for a fair trial respectively) the ECtHR has granted a much narrower margin of appreciation since those Articles are more narrowly drafted and, therefore, leave less room for government interpretation. ${ }^{72}$

The margin of appreciation has, however, not been employed in regard to Articles 2 to 4 ECHR which deal with the right to life, ${ }^{73}$ the right not to be tortured or subjected to inhuman and degrading treatment, ${ }^{74}$ and the right not to be held in slavery or servitude. ${ }^{75}$

The margin of appreciation doctrine has, according to some commentators, evolved as one of the Court's primary tools for accommodating diversity, national sovereignty, and the will of domestic majorities, while enforcing effective implementation of rights under the ECHR. ${ }^{76}$ This is

has not been consistent in the application of the "European consensus" and that, therefore, the margin of appreciation doctrine does not withstand the requirements of the rule of law, Brauch, above n 42, 128-147. Without wanting to write a length reply to Brauch's criticism the author notes that even within the personal rights some rights are more personal than others and the way the Court has applied "European consensus" as a keystone test reflects that.

71 See Ireland v United Kingdom (1979-80) 2 EHRR 25 para 207; Brannigan and McBride v United Kingdom (1994) 17 EHRR 539 para 43; Aksoy v Turkey (1997) 23 EHRR 553 para 68; Demir v Turkey (2001) 33 EHRR 43 para 43.

72 See Jeroen Schokkenbroek "The Basis, Nature, and Application of the Margin-of-Appreciation Doctrine in the Case-Law of the European Court of Human Rights" (1998) 19 Hum Rts LJ 30, 34.

73 There is still some discussion on whether to include the right to life in this category. Although the death penalty has been abolished by protocol No. 6, article 2 is still subject to some exemptions. Moreover, the Court has not fully ruled on the margin of appreciation applicable to the right to life. It has only acknowledged the existence of such a margin in the case of abortion and more specifically in determining whether the beginning of life is protected under ECHR, Article 2. However, in Pretty $v$ United Kingdom (29 July 2002, ECtHR) (assisted suicide case) compare paras 5 and 9 - the Court clearly ruled that article 2 could not be interpreted a contrario as implying the existence of a right to die.

74 Chahal v United Kingdom (1996) 23 EHRR 413 noting that ECtHR, Art 3(3) makes no provision for exceptions and no derogation from it is permissible under Article 15 even in the event of a public emergency threatening the life of the nation, para 79.

75 Christian Byk "The European approach: applying human rights principles to bioethics and the margin of appreciation of national law" (www.iales.org/archives/2008\%20croatie/coll\%2008\%20croatie\%20texte\% 20byk\%20def.pdf) (last accessed 2 March 2009).

76 It also has to be noted that the margin of appreciation doctrine is not foreign to the Inter-American Court of Human Rights (see, for example, Inter-American Commission on Human Rights, Report N 48/00 - Peru (13 Apr 2000) para 55; in regard to remedies: William Paul Simmons "Remedies for the Women of Ciudad 
so on the basis that the Court uses the doctrine to accommodate variations among state parties in their implementation of rights, while at the same time preserving the core European values they reflect. ${ }^{77}$ The success in balancing national interests and human rights protection has had authors discussing the doctrine even as a means of providing a mechanism to bring universalism and cultural relativism into an equilibrium and, therefore should be used in international human rights law. ${ }^{78}$ However, it has to be noted that the doctrine has been criticised by others. ${ }^{79}$ Critics assume that the margin of appreciation, with its principled recognition of moral relativism, is at odds with the concept of the universality of human rights. ${ }^{80}$ Others are concerned that the ECtHR's methodology in regard to the doctrine has not created a reliable enough matrix to meet the requirements of the rule of law. ${ }^{81}$

The author, like Letsas, ${ }^{82}$ notes that some of the criticism is due to some authors confusing the margin of appreciation doctrine with the proportionality test developed by the Court. The proportionality test is used by the ECtHR when assessing whether a limitation of a right was justified. Often justified limitations are already enunciated in the ECHR itself. Generally, the first limb of the proportionality test is whether the limiting act is "prescribed by law." The second limb is the actual proportionality analysis: 83

- firstly, does a statute or measure have a legitimate aim;

- secondly, the limiting measure has to be rationally connected with its aim;

- thirdly the question which needs to be answered is whether the limiting measure impairs the right or freedom no more than it is necessary for sufficient achievement of its aim; and

Juárez through the Inter-American Court of Human Rights" (2006) 4 Northwestern Journal of International Human Rights 492.

77 Howard Charles Yourow Margin of Appreciation Doctrine in the Dynamics of European Human Rights Jurisprudence (Brill, Netherlands, 1996) 6-9, 13, 49, 70-77; Douglas Donoho "Autonomy, SelfGovernance, and the Margin of Appreciation: Developing a Jurisprudence of Diversity within Universal Human Rights" (2001) 15 Emory International Law Review 391, 451.

78 Donoho, above n 77

79 George Letsas "Two Concepts of the Margin of Appreciation" (2006) 26 Oxford J Legal Stud 705; Brauch, above n 42; R Singh and others "Is there a role for the 'Margin of Appreciation' in national law after the Human Rights Act?" (1999) 1 European Human Rights Law Review 4; Eyal Benvenitsti, above n 70; Fionnuala Ni Aolain "The Emergence of Diversity: Differences in Human Rights Jurisprudence" (1995) 19 Fordham Int'L LJ 101.

80 Eyal Benvenitsti, above n70.

81 Brauch above n 42; and Eyal Benvenitsti, above n70.

82 Letsas, above n 79, 706.

83 Compare Handyside, above n 46, paras 53-59. 
- lastly whether the limit is in due proportion to the objective.

The margin of appreciation doctrine helps answer the question whether the limiting measure impairs no more than is necessary. The confusion stems from the Court sometimes developing both doctrines at the same time, as it did in Handyside $v$ United Kingdom, ${ }^{84}$ on other occasions not clearly distinguishing between both concepts and, itself, using the nomenclature of margin of appreciation when substantively balancing a right against a common good. ${ }^{85}$ The margin of appreciation doctrine is part of the proportionality analysis. The doctrine becomes relevant when the Court has to decide whether a rights infringement was "necessary".

In the author's view the two examples show that the margin of appreciation by the ECtHR has proven to be a useful doctrine to take account of the "peculiarities" of the individual member states which have diverse religious, social and historic backgrounds. ${ }^{86}$ Furthermore, by affording rights a wider and a narrower margin of appreciation the ECtHR could also be seen to establish a hierarchy of rights. ${ }^{87}$

\section{HOW WOULD THE MARGIN OF APPRECIATION DOCTRINE WORK IN THE PACIFIC?}

After the description of how the ECtHR has used the margin of appreciation doctrine and after describing the use of human rights norms in the Pacific the question arises whether margin of appreciation would add anything to a regional human rights framework. The examples in the domestic courts have shown that judges are already well aware of the tension between human rights as enshrined in the international instruments and traditions and are well able to find a balance. In fact, the argument that traditions and customs cannot be upheld under a Western style human rights mechanism is often heard but not necessarily substantiated by concrete examples. However, recognising that distinct cultural differences exist in the Pacific the use of the margin of appreciation doctrine in a regional human rights mechanism would first and foremost provide a basic doctrine and a framework for the balancing occurring in numerous courts already. Secondly, it will provide a solid base doctrine for any arising conflict between human rights articulated in a regional mechanism and customs and traditions.

84 This case doubles as an important one in the development of the proportionality analysis in human rights law which is now part of human rights methodology worldwide, see, for example, NZBORA, s 5; Canadian Constitution Act 1982, s 1; and South African Constitution, Art 36; BVerfGE 3, 383, 398, 399.

85 See in regard to an extensive discussion of the use of margin of appreciation by the ECtHR and its theoretical underpinning, Letsas, above $n 79$.

86 See also Donoho, above n 77.

87 This paper does not have the room to explore any arguments in regard to the validity of a hierarchy of rights. 


\section{A General}

As stated in the introduction, ${ }^{88}$ the Pacific is the one of the most diverse places on earth. The total population of Pacific Island countries and territories was 9.5 million in 2008, ${ }^{89}$ while Australia and New Zealand between them comprised another 25 million people. ${ }^{90}$ In Papua New Guinea alone 860 languages are spoken. ${ }^{91}$ However, as the New Zealand Law Commission has pointed out, ${ }^{92}$ notwithstanding all their diversity Pacific Island people to a certain extent share culture and language, custom law, their small scale, their oceanic nature, their colonial past, ${ }^{93}$ Christianity as the main religion in the Pacific, agriculture and fisheries as the mainstay of their economies, and that often expatriates provide a significant source of income. Pacific Island countries and territories are vulnerable to natural disasters like cyclones and face major environmental challenges, such as global climate change and sustainability of fish stocks. Urbanisation in the Pacific is high. A country-by-country analysis shows that in 11 out of 22 Pacific Island countries and territories, more than half the population lives in urban areas. ${ }^{94}$

In comparison it would be erroneous to believe that Europe is a unified continent. Even though there might not be as many different languages spoken and there might not be as many different cultural groups as in the Pacific, there are significant differences in the languages, histories and social structures of Europe's states. On the other hand, Europe's states share history, social and economic realities and sometimes language and but so do the Pacific states. One feature which makes the Pacific region unique is that it consists of many small islands and that the biggest mass in the Pacific region is the ocean. ${ }^{95}$ This is not conducive to raising awareness among the Pacific Island people of the culture and history they share and about where they differ, which potentially might impact on the acceptance of any regional court decision. The Pacific is also unique in that in comparison to Europe there is no distribution of small and big states. Australia has more than double

88 See above fn 1.

89 Statistics \& Demography, The 2008 Pocket Statistical Summary (www.spc.int/sdp/index.php?option =com_frontpage\&Itemid=1) (last accessed 24 Feb 2009).

90 Statistics \& Demography, The 2008 Pocket Statistical Summary www.cia.gov/library/publications/theworld-factbook/print/as.html (last accessed 24 Feb 2009)

91 Freda Talo "Country Report Papua New Guinea" (2009) 40 VUWLR (forthcoming).

92 New Zealand Law Commission Converging Currents: Custom and Human Rights in the Pacific, above n 3 , paras 2.8-2.9.

93 All of the Pacific except for Tonga experienced colonization at some point from the late eighteenth to the twentieth centuries.

94 New Zealand Law Commission Converging Currents: Custom and Human Rights in the Pacific, above n 3 para 2.5.

95 This feature does not play a direct role for the discussion in this paper However, it is significant in regard to the development of a regional mechanism/charter. 
the citizenry of all the Pacific Islands together. New Zealand is the second biggest state but has only roughly a fifth of the population of Australia. Europe consists of a multitude of differently sized states. There are big ones like France, Germany and the United Kingdom and small ones like Malta, Austria, or Switzerland (all rather populous in comparison with the smallest of the Pacific Islands like Niue, not to mention Pitcairn). Can the margin of appreciation doctrine be used or will a court or regional human rights commission be overwhelmed by the multitude of differences? Or will it run into the danger of giving greater weight to Australia's and New Zealand's customs and traditions than that of the other Islands?

In the author's view, a regional Pacific human rights instrument should incorporate a margin of appreciation doctrine. When asking the question whether the limitation of a right is justified - a question which will have to be asked whatever form a Pacific human rights instrument might take, the court or the regional human rights commission should take into account whether the particular limitation was justified in light of the customs of the country in question - whether is was "necessary". The court should closely examine the historical and social context of why the state had limited the right and then engage in a comparative analysis. New Zealand Law Commission has already identified certain common values. There are other precedents for the identification of common values in the Pacific: ${ }^{96}$ in a schoolbook on civic education, Transparency International Vanuatu proposes that students discover custom, Christian and civic (or human rights) values to determine the values on which Vanuatu is founded. ${ }^{97}$ In research for the Foundation of the Peoples of the South Pacific international (FSPi), villagers were canvassed on customary values in developing an understanding of good governance and leadership principles. ${ }^{98}$ A search for customary values was also undertaken by the International Committee of the Red Cross (ICRC) Regional Delegation for the Pacific in order to connect international humanitarian law with Pacific peoples. ${ }^{99}$ The use of a margin appreciation doctrine by a regional human rights court/commission would lead to the continuous identification of the key values in the particular customary communities in comparison to the wider Pacific community.

96 New Zealand Law Commission Converging Currents: Custom and Human Rights in the Pacific, above n 3, paras 6.16.

97 Transparency International: "TI Vanuatu has also developed civics curricula for secondary schools. Topics include civics, ethics/values, democracy, human rights, gender equity, and good governance. In addition, the Chapter has prepared training materials for teachers." (www.transparency.org) (last accessed 3 April 2009).

98 Foundation of the Peoples of the South Pacific international RETA 6065: Assessing Community Perspectives on Governance in the Pacific (report to the Asian Development Bank, Suva, 2003) www.fspi.org.fj (last accessed 23 Jan 2009).

99 ICRC Regional Delegation for the Pacific Even Wars Have Limits: Connecting IHL with the Pacific Way (draft paper, June 2005). 
The comparative analysis should include Australia and New Zealand. However, no more weight should be given to established practices in those two countries than in the other, smaller Island states. Indeed, it has to be taken into account that both countries have indigenous populations. Australia and New Zealand are not alone. Many of the Pacific Islands have indigenous populations and/or accommodate more than one culture. The court/commission will have to take account of that as well and should treat those as a separate entity. Of particular interest in certain circumstances can be whether certain customs and traditions were still practised among Pacific Islanders living in New Zealand. Another important point in the analysis is that customs are not static but also develop and "go with the times."100

On the other hand, a margin of appreciation analysis would give a regional court the opportunity to emphasise certain rights by affording them a wider or narrower margin of appreciation. For example, when it comes to the right to life and health "traditions" of excessive corporal punishment will not find a necessary basis in any of the other traditions and might objectively not be seen as "necessary". As Jalal points out Pacific peoples and Pacific culture are not so different that international human rights standards and norms ought not to apply. ${ }^{101}$ On the other hand in regard to freedom of expression the court/the commission might decide to afford a wider margin of appreciation so that in the New Zealand context the speaking rights of women on the marae might be seen as justified in regard to an equality clause. ${ }^{102}$

In conclusion, the use of the margin of appreciation doctrine will enable a court/regional human rights commission on the one hand to ensure that Pacific people are not lesser people but that they are entitled to the same rights as all other peoples on earth. On the other hand the use of the doctrine will allow to be taken customs, traditions, and the state's history, into account. As the ECtHR has shown in Sahin $v$ Turkey historical and particular constitutional circumstances can be taken into account and lead to a nearly counter-intuitive judgment. The court will have to embark on a balancing exercise to decide which rights afford a narrower and which ones a wider margin of appreciation. Some authors fear that the use of "margin of appreciation" could lead to an eroding of the universality of human rights. ${ }^{103}$ This fear might be particularly pertinent in the Pacific where there is a widespread scepticism in regard to human rights. However, the margin of appreciation

100 Marsack CJ in Mose v Masane above n 29

101 Jalal, above n 6.

102 See the informative discussion in Claire Charters "Universalism and Cultural Relativism in the Context of Indigenous Women's Rights" Human Rights Research (www.victoria.ac.nz/nzcpl/HRRJ/vol1/Charters.pdf) (last accessed 3 March 2009) 3; but also see Bullock v Department of Corrections [2008] NZHRRT 4 (19 March 2008) where the HRRT held that it was discriminatory that women could not speak at a Government department's powhiri and had to sit behind the men

103 See above Brauch, above n 42 and Eyal Benvenitsti, above n70 
doctrine, in the author's view, does not erode the universality of human rights. The doctrine merely acknowledges that the limitation placed on a right can be different in different societies. However, that does not mean that the doctrine can be applied to reduce a right to virtually nothing or erode a right substantially. As the ECHR has pointed out in Handyside: "[t]he domestic margin of appreciation thus goes hand in hand with a European supervision. Such supervision concerns both the aim of the measure challenged and its 'necessity'". ${ }^{104}$ National case law suggests that judges are already aware of the balancing required between custom and tradition and human rights enshrined in their constitutions and are able to conduct that balancing. It is, therefore, unlikely that a regional court or a regional human rights commission would use the margin of appreciation doctrine to erode rights. However, the benefit of enshrining the doctrine into a regional human rights mechanism rather than letting a future court or regional human rights commission develop it is that the drafters would be able to stipulate clearly what the judges in Handyside emphasised that the margin was not "unlimited". 105

\section{B Application}

What difference would the use of the margin of appreciation doctrine make in the cases already mentioned? In the cases where the courts have already balanced and taken account of human rights, the margin of appreciation doctrine does add a balancing framework to the decisions and ensures that the courts take the Pacific region and its customs into account. In regard to the High Court of Tuvalu's 2005 decision a comparative analysis by a regional human rights court would have found that other courts had taken international human rights treaties they had ratified into accounton as well as the significance of land in Pacific societies. ${ }^{106}$ The significance of the latter, the fact that it is a common feature in Pacific societies, and Tuvalu's emphasis on traditional values as an overriding condition for the exercise of some rights in its Constitution, ${ }^{107}$ might have not altered the court's decision.

104 Handyside v United Kingdom, above n 46, para 49.

105 Idem.

106 See Farran, above n 7, 125-130.

107 Tuvalu Constitution, Art 29 Protection of Tuvaluan values, etc.

(1) The Preamble acknowledges that Tuvalu is an Independent State based on Christian principles, the Rule of Law, Tuvaluan values, culture and tradition, and respect for human dignity.

(2) This includes recognition of-

(a) the right to worship, or not to worship, in whatever way the conscience of the individual tells him; and

(b) the right to hold, to receive and to communicate opinions, ideas and information.

(3) Within Tuvalu, the freedoms of the individual can only be exercised having regard to the rights or feelings of other people, and to the effect on society. 


\section{CONCLUSION}

When a Pacific human rights mechanism is drafted the margin of appreciation doctrine should be included in such a mechanism. The doctrine will allow the courts/human rights commission to take account of Pacific Island customs and traditions and/or their historic, cultural, and social "peculiarities". As Sahin has shown, the particular history of a country can be taken into account. It will, however, also guarantee at the same time that Pacific peoples will not be afforded lesser human rights.

(4) It may therefore be necessary in certain circumstances to regulate or place some restrictions on the exercise of those rights, if their exercise-

(a) may be divisive, unsettling or offensive to the people; or

(b) may directly threaten Tuvaluan values or culture.

(5) Subject to section 15 (definition of "reasonably justifiable in a democratic society") nothing contained in a law or done under a law shall be considered to be inconsistent with section 23 (freedom of belief) or 24 (freedom of expression) to the extent that the law makes provision regulating or placing restrictions on any exercise of the right-

(a) to spread beliefs; or

(b) to communicate opinions, ideas and information;

if the exercise of that right may otherwise conflict with subsection (4). 